Assistant Professor Piotr Plichta, PhD hab., https:/ / orcid.org/0000-0002-9238-0113

Institute of Pedagogy

Faculty of Historical and Pedagogical Sciences

University of Wroctaw

\title{
Supporting school inclusion of students with disabilities and special educational needs \\ - selected challenges and solutions
}

\author{
Jak wspierać proces inkluzji szkolnej uczniów \\ $\mathrm{z}$ niepełnosprawnościami i specjalnymi potrzebami edukacyjnymi \\ - wybrane wyzwania i propozycje rozwiązań ${ }^{1}$ \\ https://doi.org/10.34766/fetr.v47i3.787
}

\begin{abstract}
Nowadays, a fairly widely accepted idea regarding education is that schools should provide an inclusive environment. However, the process of inclusion cannot be accomplished spontaneously. If such a process is not actively supported, it may contribute to the growth of intolerance, stereotypes, exclusion and school violence. If inclusive education is to become more than merely a slogan, it is necessary to provide support to all involved, including teachers. In light of the research, the selfassessment of teachers' competencies in educating students with developmental disabilities and special educational needs is relatively low. The article describes possible challenges in making schools more inclusive environments and proposes possible means of supporting teachers in selected areas of inclusion.
\end{abstract}

Keywords: disability, inclusive education, school inclusion, social health, special educational needs

\begin{abstract}
Abstrakt: Współcześnie, dość powszechnie akceptowanym poglądem dotyczącym szkoły jest, to że powinna być środowiskiem włączającym. Jednak proces inkluzji nie odbywa się samorzutnie, jedynie poprzez fakt przebywania $\mathrm{w}$ tej samej przestrzeni klasy szkolnej uczniów z niepełnosprawnościami, specjalnymi potrzebami edukacyjnymi i ich tzw. pełnosprawnych rówieśników. Co więcej, jeśli proces taki nie jest wspierany, może przyczyniać się do wzrostu nietolerancji, utrwalania stereotypów, wykluczenia i przemocy szkolnej. By zatem edukacja włączająca nie była jedyni sloganem, konieczne jest wsparcie dla wszystkich uczestników tej sytuacji, w tym dla nauczycieli. W świetle badań, samoocena ich kompetencji $\mathrm{W}$ zakresie pracy $\mathrm{z}$ dziećmi $\mathrm{z}$ zaburzeniami rozwojowymi, niepełnosprawnościami nie należy do wysokich. Tekst ten poświęcony jest charakterystyce wybranych wyzwań związanych z inkluzja szkolną i zaproponowaniu rekomendacji wspierających nauczycieli w tych sferach.

Słowa kluczowe: edukacja włączająca, inkluzja szkolna, niepełnosprawność, specjalne potrzeby edukacyjne, zdrowie społeczne

"(...) the inclusion of children with disabilities is one of the most complex and poorly understood areas of education" (Lindsay, Proulx, Scott, Thomson, 2014, p. 102).
\end{abstract}

\footnotetext{
${ }^{1}$ Polska wersja: https://stowarzyszeniefidesetratio.pl/Presentations0/2021-3-Plic.pdf
} 


\section{Introduction}

At present, a relatively widely accepted (at least on a declarative level) view is that schools should provide an inclusive environment. In other words, it is assumed that students, when faced with the variety of differences that exists among their peers (for example, regarding their level of ability, health and social functioning) will develop attitudes that lend themselves well to functioning in inclusive societies. For those experiencing more serious difficulties, schools should provide a space to experience a sense of belonging, of feeling valuable and of social well-being, or at least, at the bare minimum, a sense of safety within the school environment. This is not merely a humanistic postulate, but a human rights issue. It is important to emphasise that such a process is not something that will happen automatically simply as a result of placing students with and without disabilities within a shared school space. If these processes are not supported, such a situation can even contribute to rising intolerance and reinforcement of stereotypes. "It cannot be said that spending time together necessarily brings people closer, sometimes it can separate them further" (Kowalik, 2001, s. 47). Supporting all participants in these situations is therefore crucial. That also includes teachers, who bear the responsibility for handling a variety of serious challenges daily, including creating an inclusive environment free of discrimination based on ability, health and developmental difficulties. Exclusionary practices have a negative impact on the social atmosphere in educational facilities, feeding into rising inequalities, conflicts and an overall sense of distrust. The considerations presented here are primarily relevant to the situation of children and youth who study at general schools. Certainly, the issues surrounding health, support, social relations and participation are worth discussing in the context of special education schools as well, but due to the differences in the social and organisational contexts and the staff preparation, they require separate consideration.

The analysis presented here is of a general character due to, among others, the wide scope of the issues under discussion. There are numerous reasons for this, such as the great diversity of the group described as 'disabled', and the complexity of issues surrounding the processes of inclusive education (Szumski, 2019).

\section{School inclusion and social health}

In evaluating the overall school functioning of students (its quality and effectiveness, also regarding inclusion and evaluating its efficacy), it is important to pay attention to its different dimensions: academic (regarding learning, results, achievements etc), emotional 
(the attitude towards school, liking or disliking it) and social (for example, relations with others). It is the last aspect that is the primary focus of my investigation, even though these dimensions certainly co-exist, overlap and exert influence over one another. In the fifteen proposed classifications of dimensions of health analysed by K. Walentynowicz-Moryl (2016) along with the self-explanatory physical aspect, a social dimension is always present. Its specific character stems from the fact that "the range of social health exceeds the boundaries of an individual, it is in part situated outside (Heszen, 2005)". It concerns a particular person and, at the same time, speaks to the wider (so-called) social health.

The relationship between health and social issues is also expressed in the indicator of social health proposed by F. Jany-Catrice (2009). One of its six dimensions relates to inequalities. The researchers point to a range of variables that determine the social aspects of health, such as the quantity and quality of interpersonal bonds, the range of social engagement, functioning within social roles and the satisfaction derived from them, autonomy, communicative abilities and the network of friends (Walentynowicz-Moryl, 2016) etc. It is important to emphasise that a lack of friendship is one of the primary risk factors of becoming a victim of peer group bullying (Plichta, 2010). A reader can easily find a range of sources showing that concerning the aforementioned dimensions of social health, persons with disabilities experience difficulties and in comparison to the general population achieve lower indicators (such as higher levels of loneliness, less engagement with social roles and higher rates of dependency on others). This indicates, among others, the conceptual proximity of the social aspect of inclusion and the social aspect of health.

\section{Special educational needs and the risk of exclusion}

There is a considerable group of young people who require higher than average levels of support in the realisation of their educational needs (often described as special educational needs). For example, the results of the TALIS survey indicate that around $60 \%$ of Polish teachers work in schools in which the degree of students with diagnosed special educational needs exceeds 10\% (Henrik et al., 2014). While on one hand, it is a positive measure to identify the group which requires higher levels of support, on the other, it is important to keep in mind the risk of wrongfully ascribing this group of an incredibly diverse character with certain shared characteristics.

The differences between young people with disabilities may concern the type of disability (sensory, motor, intellectual), its level (for example mild, moderate or severe), the need for support and resources, abilities, coexisting issues, but also the strong suits, interests, temperament, character traits etc. Under educational law (MEN Directive, 2017), the group of people described as having special educational needs also includes students with chronic illness, those undergoing crises, those with learning difficulties, but also those with 
extraordinary abilities. At times, such young people require support in more than one area of special educational needs. It is one of the difficulties in formulating recommendations for such a diverse group. Their school situation can be vastly different depending on the type of disability they have, and the greatest difficulties tend to be experienced by students with intellectual disabilities (Buchnat, 2019).

As P. Hutchison, D. Abrams and J. Christian (2005) note, exclusion violates a fundamental human need of belonging to a social group, being deprived of which brings many negative consequences (such as lower self-esteem, anxiety, anger, self-blame, difficulties concentrating). For some, experiencing exclusion may bring about antisocial and aggressive reactions, while others develop more passive reactions such as withdrawal and self-harm. It can also lead to succumbing to the majority's expectations, which is not always a constructive strategy. The perception of 'Others' as violating the needs or norms of a specific community may lead to the group developing intolerant outlooks and making attempts at increasing the in-group coherence by isolating and excluding certain individuals. Therefore, strategies that promote integration within the group (such as resitting students and working in diverse teams) and create a group identity centred around shared goals can be guidelines to follow in preventing exclusion.

\section{The risk of focusing on disorders}

It is important to note that perceiving someone through a diagnostic label can, outside of providing some benefits (such as identifying those requiring assistance), lead to the danger of overlooking the person's qualities outside of their disability. Formal diagnoses influence the school situation of such students. For example, D. Shifrer (2013) speaks of adults' lowered expectations towards students with a diagnosed learning difficulty. Rather than using the label of 'special educational needs', I consider the description of 'students requiring a special realisation of educational needs' a more fitting category. Seen from this perspective, the focus is not the needs being somehow 'special', but on the fact that some people simply require more support and assistance in finding ways of having these needs met. Overlooking or ignoring the universality of educational needs may engender a perception that there is a distinct group that requires something unique or special. Most often, however, it concerns resources that should be accessible to all, and what is needed is simply to make them accessible to those in more complicated situations. Educational needs (Głodkowska, 2019) such as curiosity, cognitive exploration, a sense of self-worth, interpersonal communication and self-determination (self-directedness?) are of a universal character. Understanding this counters the myth of the nature of needs as specific only to some. 
One of the most important aspects of work in education is to pay attention to students not merely through the lens of their diagnosis ('what's wrong with them') as the need to be seen and to receive positive attention is shared by everyone. Paying attention to the person and not their specific attributes can constitute an important compensatory mechanism because the people in question often receive attention which is not rooted in an interest in who they are, but in the difficulties or problems they experience, perceived through the lens of their disability or disorder.

Special education needs and disabilities constitute "all-inclusive" minorities (Riley, 2006), which means that the behaviours of those with such diagnoses are not perceived through the same categories applied to others, with the disability itself seen as the root cause of their issues instead. A closely related conceptual category is that of diagnostic overshadowing in the context of recognising so-called 'difficult behaviours', meaning new symptoms experienced by those with intellectual disabilities or autism, which then serve as an all-purpose explanation of their behaviour (for example, 'that's just what autistics do'). As a consequence, the same issues in non-disabled students are interpreted as having other explanations (they are caused by stress, disadvantageous circumstances or poor mental wellbeing) than their peers with official diagnoses.

\section{The role of teachers in school inclusion}

The importance of modelling behaviour towards students with disabilities by teachers cannot be overlooked. This is reflected in the statement made by a parent participant in a research study: "You teachers can have immense influence - positive or negative - on how other students perceive a child with a disability. As leaders within the school environment, you shape the in-class atmosphere. Be mindful of not creating one which encourages others to persecute a child with autism" (author's translation from Sciutto, Richwine, Mentrikoski, Niedzwiecki, 2012). Examples of stigmatising experiences (Mueller, 2019) of young people with special educational needs are not merely situations rooted in peer behaviour; such experiences can also be caused by teachers (for example, being placed in a group of those with lower abilities in a certain field). Some research subjects pointed to specific moments in which they realised they are different from others, even though they did not previously perceive themselves as such. Other studies indicate that teachers' selfassessment of competence in working with children with developmental disorders and disabilities is not high (Plichta, 2019). Similarly, the quality of offered training in working with such students is appraised as low. It is important to emphasise this within the overall diagnosis of the described context as teachers are often on the receiving end of unfair judgment, whereas they are also in need of support. Sometimes the issues experienced by a 
student with a disability require a multimodal, specialised approach which exceeds the capabilities of a single, often inadequately trained person.

Although there are many issues we have limited influence on (such as educational policy and the contents of the curriculum), we do have freedom in adopting appropriate perspectives on in-school issues and dynamics which are key in shaping our relationships with students and influence them to a high extent. Assuming an understanding perspective (Olechnowicz, 1999) by teachers is expressed in their willingness to approach children with understanding, also towards their difficult behaviours, and being prepared to search for answers and engage with complex issues. In practice, this is expressed by developing certain hypotheses, applying appropriate methodologies and testing their efficacy. If the need arises, it is also crucial to repeat these steps and re-test.

A key element of a teacher's skill set is diagnostic skills. This is reflected in the words of Janusz Korczak (1924): "What fever, cough and vomiting are to a doctor, a smile, a tear or a blush are to a teacher. There is no symptom without meaning. One must note and consider everything, reject the accidental, connect the meaningful, search for underlying laws". Within the scope of these considerations, this will largely concern recognising the psychosocial situation of students with disabilities or developmental difficulties. The benefits of learning in an environment shared with their typically developing peers do not merely give a chance for higher educational achievement, but also significantly impacts socioemotional functioning, which is reflected, among other factors, in the quality and quantity of social bonds (Venetz, Zurbriggen, Schwab, 2019). A large majority of research on the effects of inclusion (especially older studies) were focused on academic results and many of them indicated that students with special educational needs perform better in such environments rather than in separate schools. Newer analyses pay more attention to the socio-emotional aspects of inclusion, such as acceptance within the class environment. These studies indicate that students with SEN are often less accepted (Schwab, 2015) and evaluate their time in school in a more negative way than the rest of their peers (Skrzypiec et al., 2016).

The diagnostic skills of teachers should be reflected, among other things, in their attempt to understand so-called difficult behaviours. For students with disabilities, many aspects of the school environment (such as noise, unpredictability, learning spaces not being adapted appropriately, interactions with peers, an abundance of stimuli) may trigger problematic behaviours. Although the majority of research points to the heightened risk of becoming a victim of peer bullying among people with disabilities, in some cases it is their aggressive behaviours that can be a problem, the causes of which tend to be overlooked. According to A. Kaukianen and his fellow researchers (2020, p. 276), participating in peer violence may be interpreted as attempts at establishing one's position within a group, which can otherwise be difficult, with bullying then "representing their awkward, desperate attempts at struggling to keep one's face" (author's translation). 
It is also important to note that the precision with which teachers evaluate the socioemotional aspect of inclusion is not often investigated. However, the data gathered indicates large discrepancies between the self-evaluation of students and their appraisal by adults. Research centred around attitudes towards the inclusion of students with disabilities makes it apparent that teachers overestimate the social standing of students with special educational needs. Positive socio-emotional indicators are then clearer and more precise means of evaluation than negative responses ( $\mathrm{Zhu}$, Urhanhne, 2014) such as isolation and rejection. This can partially be explained by the fact that some of the issues experienced by students are not easily noticeable for teachers (such as their emotional state and difficulties with peer relationships). Teachers overestimate the emotional aspect of inclusion - in other words, students with special educational needs enjoy school less than teachers tend to think.

Retrospective research on students (Venetz et al., 2019) usually presents a more positive view of the school environment than current studies. This 'rosy view effect' points to the need for creating opportunities to talk to students and discover their opinions, keeping in mind that they are not always prone to discussing the experienced issues spontaneously (usually, data on students with disabilities comes from the perspective of their able-bodied peers and teachers). In light of this, an important recommendation for working with students requiring extra support is that the teachers be proactive, not merely in responding to the students existing issues and diagnosing them, but also in preparing the whole class for the inclusion of a new student, especially one with a disability. Such efforts preceding the arrival of new students are compared by K. Novak and D. Rose (2016) to preparing a buffet for guests. Upon their arrival, something could be whipped up spontaneously, but it's better to anticipate different culinary preferences. Currently, such an approach to education is described as UDL - Universal Design for Learning. It is based on the assumption that it is possible to differentiate efforts, requirements and manners of motivating in such ways that they can encompass all students.

\section{The importance of regularity in pro-inclusion behaviours}

"In education, a variety of seemingly trivial issues might come with serious consequences" (Meirieu, 2003, p. 43).

In educational work, it is worth appreciating the importance of everyday, regular activities. In schools, we often encounter event-like efforts, such as organising particular days/weeks/workshops devoted to a particular problem, which can enable an increased awareness and a building of consciousness around it. However, it is the repeated, everyday gestures that play the biggest role in shaping attitudes, for example towards people with disabilities. 'Attitudes' are among the most used (perhaps overused?) buzzwords in 
education. Considering its definitional meaning, an attitude is something of a relatively stable character, meaning it takes a relatively long time to acquire and an equally long time to unlearn. In pedagogic work, we cannot forget about tailoring our efforts to the different aspects that comprise an attitude, which is said to include three components: an emotional, cognitive and behavioural one. Therefore, when striving to have a positive impact on shaping attitudes, our actions should be geared towards expanding the students' knowledge (for example, on what disability is), emotionally engaging them (building empathy) and teaching specific behaviours (for example ways of reacting when witnessing a person with a disability struggling with a difficulty). There is an impression that too often, pedagogically important questions are only talked about (in a one-way manner, with a teacher warning, postulating etc.) Such an 'overtalked' preventative approach is hardly adequate in the face of serious challenges such as issues of social inclusion which are reflected in the everyday dilemmas regarding fair grading, the treatment of others or showing respect. It is important to emphasise that when considering effectiveness, it is apparent that regular efforts that are present in everyday practice are more effective than 'special occasion' ones.

\section{The need for reflection on the details of the undertaken efforts}

Reassigning students to different seats seems one of the most obvious, common measures used in the classroom environment. However, in most cases, it is used as a punitive mean to discipline a student for something like talking to another student during class. Used as such, it is hard to notice the immense potential of this measure. J. Pyżalski (2019) points to the pedagogic aspect of reassigning seats and its capability to generate everyday encounters between different students. Keeping in mind the important limitations of this practice, it is essential to introduce rules around seat reassignment, incorporating this strategy in new class settings, notifying students that the arrangements are temporary and there will be regular changes, that the assignment is made at random. The students' parents must be notified of this measure and its intended goals. In cases of specific special educational needs, it is important to remember that this method will be of limited use, for example, due to the strong need for environmental stabilities in students on the autism spectrum.

Another method intended to improve the understanding of certain students' situations described by J. Pyżalski (2019) is organising educational sessions (talks, workshops) about the specifics of special educational needs. Despite their great educational potential, they can be counterproductive if they are forced by a teacher without consultation with students and their parents. Such approaches necessitate preparing the student with special educational needs in ways that respect their autonomy and the right to decide to what extent such meeting may touch upon their personal situation. 


\section{The risk of overprotection}

It is important to note that out of good intentions (such as caring for the safety of students with special educational needs), a mistake can be made in overprotecting them. Research shows decisively that students with disabilities experience a higher risk of social isolation (Plichta, 2019). On one hand, there is a need for attention which is crucial in recognising different, sometimes easily overlooked symptoms of mistreatment or exclusion from class life. On the other, it is important to be mindful of not going overboard in making such protectiveness visible as it can send a further signal to peers of the difference and 'weakness' of the student with special educational needs. Such attitudes in adults might be a risk factor in the process of becoming a victim of peer aggression. Another aspect of 'overprotecting' is interfering with the process of emancipation, learning coping mechanisms and participation in normal interactions.

In short, a 'deficit model' is based on seeking to 'fix' students and concentrates on issues that are not changeable, on limits and barriers. Currently, strength-based approaches are proposed in their place (Wehmeyer et al., 2017). Such approaches focus on opportunities for growth, potential, resources, creating an individualised programme of support and trying to see school as part of a wider context of the students' lives and their future. Naturally, efforts to solve problems through different means of improvement cannot be overlooked in professional pedagogic work. However, it is essential to acknowledge the importance of the second pillar crucial to the achievement of assumed aims (not just our aims, but also those of the person we seek to support). This pillar stands for searching for the person's strengths and harnessing them in educational work.

\section{The need for supporting parents of students with special educational needs}

An important issue necessitating wider consideration is the need to increase the teachers' sensitivity to the singular and often very difficult situation of parents of children with disabilities and developmental disorders. This is a group characterised by a high degree of diversity - among them, there are those in relatively advantageous situations, along with others who need a high level of support. In schools, there exists a need for something more than simply responding to the support needs as expressed by parents. Proactivity in this area is important (for example, inquiring how the parents are doing and whether they need assistance). Research shows that even in special schools this is not common practice (Pyżalski, Plichta, 2015). Working together is an often-postulated form of parent-teacher

relations. However, the need for help should not be overlooked. Parents are not always capable of engaging in cooperation, but there is a high probability they will experience 
a need for support (it is experienced by up to $90 \%$ of parents of children with disabilities and half of them require assistance in more than one area, for example, material and emotional support at the same time) (Douma et al., 2006). Another aspect of relationships with parents is opening up to their perspective and knowledge about the child and their needs (for example in terms of formulating educational goals and planning for the future). It seems that to postulate giving basic respect is banal but in light of the research results, it is not just children with disabilities themselves but also their parents that encounter inappropriate treatment. "Here (in a special school - author's note) all the children are the same and nobody is surprised by anything. The kids feel important and we as parents also feel understood; the teachers treat us in a friendly, compassionate way. It's not like in other schools" (Pyżalski, Plichta, 2015).

\section{Educational priorities in the time of a pandemic}

As this text has been written at a particular time (the third wave of the pandemic of the SARS-CoV-2 virus, which causes the COVID-19 disease), it is important to note a few issues around distance learning. They can help to better care for students in more difficult situations, experiencing various inequalities, including digital ones. These can be different: from infrastructural issues (such as access to modern devices or broadband internet), digital competencies or received support. M. Kent and K. Ellis (2015) note that decreased access to new technologies puts those with disabilities in more disadvantageous positions when extreme situations arise. These inequalities are not necessarily caused by disabilities or developmental disorders but they might to a higher degree affect children in special residential centres, child care homes, foster care and large families. A priority area for support in distance learning during the crisis is not merely to concentrate on teaching, but maintaining and strengthening relationships with other people (such as teachers and peers). W. Poleszak and J. Pyżalski (2020) emphasise that one of the most important support factors in situations of crisis (meaning sudden situations causing strong emotions, primarily fear, that disorganise everyday life and trigger defence mechanisms) in the sense that we are not left alone with the problem.

It is also important to make sure that the expectations placed on students are flexible, for example in terms of the tasks they need to carry out and their documentation (such as allowing them to use mobile phones). The internet can also serve as a tool for providing instructions for parents (for example as teacher-prepared video materials explaining how to correctly do a specific exercise together with the child). Distance learning presents a risk situation in which existing inequalities (such as poverty, learning difficulties and loneliness) may deepen. Therefore, it is advised to use methods that are as non-exclusionary as possible. Among others, it is about keeping a balance between synchronic methods (such as online 
classes in real-time) and asynchronous ones (such as recordings, podcasts and tutorials). The latter category minimises the difficulty of participating in a class at an arbitrary time. "An asynchronous teacher presence (in the form of pre-prepared video materials, explanations, instructions or guidelines) is also a good solution for students who, when using these resources, have an unlimited capacity to go back to something unclear to them without having to ask the teacher to repeat something. In a traditional classroom setting, this can be difficult due to both psychological reasons (feelings of awkwardness, shame and uncertainty), as well as time constraints" (Plichta, 2020, p. 76).

In the case of students who possess limited resources for dealing with the challenges of the present situation (such as students on the autism spectrum, with intellectual disabilities, chronically ill or experiencing other crises), it is not the didactic aspect that is a priority today, but questions of basic needs, such as safety and belonging. As a finishing remark, I refer to J. Humphrey's and N. Hebron's (2015) view that if the inequalities in the real, everyday social participation (for example in the classroom environment, but also in relationships outside of school) of young people with disabilities are not limited, the rhetoric of the benefits of inclusive education will remain an empty slogan.

\section{Bibliography:}

Buchnat, M. (2019). Percepcja klimatu szkoty przez uczniów z lekka niepetnosprawnościa intelektualna $w$ trzech formach kształcenia a agresja $i$ przemoc szkolna, Poznań: Wydawnictwo Naukowe UAM.

Douma, J.C.H., Dekker M.C., Koot, H.M. (2006). Supporting parents of youths with intellectual disabilities and psychopathology, Journal of Intellectual Disability Research, 50, 570-581, https:// doi.org/10.1111/j.1365-2788.2006.00825.x.

Gajdzica, Z. (2011). Sytuacje trudne w opinii nauczycieli klas integracyjnych, Kraków: Oficyna Wydawnicza Impuls.

Głodkowska, J. (2019). Dydaktyka specjalna. Od wzorca do interpretacji, Warszawa: PWN.

Hernik, K., Malinowska, K., Piwowarski, R., Przewłocka, J., Smak, M., Wichrowski, A. (2014). Polscy nauczyciele i dyrektorzy na tle międzynarodowym. Główne wyniki badania TALIS 2013, Warszawa: Instytut Badań Edukacyjnych.

Heszen, I. (2005). Zmienność wymiarów zdrowia na przestrzeni życia człowieka, (w:) D. Kubacka-Jasiecka, M. Ostrowski (red.), Psychologiczny wymiar zdrowia, kryzysu $i$ choroby 21-36, Kraków: Wydawnictwo Uniwersytetu Jagiellońskiego.

Humphrey, N., Hebron, J. (2015). Bullying of children and adolescents with autism spectrum conditions: a 'state of the field' review, International Journal of Inclusive Education, 19 (8), 845-862, https:/ / doi.org/10.1080/13603116.2014.981602. 
Hutchison, P., Abrams, D., Christian, J. (2005). The Social Psychology of Exclusion, (in:) D. Abrams, M. Hogg, J. Marques (red.), The social psychology of inclusion and exclusion, 29-57, New York: Psychology Press.

Jany-Catrice, F. (2009). The French Regions and Their Social Health, Social Indicator Research, 93 (2), 377-391, https:/ / doi.org/10.1007/s11205-008-9330-8.

Kaukiainen, A., Salmivalli, C., Lagerspetz, K., Tamminen, M., Vauras, M., Mäki, H., Poskiparta, E. (2002). Learning difficulties, social intelligence, and self-concept: connections to bully-victim problems. Scandinavian Journal of Psychology, 43 (3), 269278, https://doi.org/10.1111/1467-9450.00295.

Kent, M., Ellis, K. (2015). People with disability and new disaster communications: access and the social media mash-up, Disability $\mathcal{E}$ Society, 30 (3), 419-431, https:/ / doi.org/10.1080/09687599.2015.1021756.

Korczak, J. (1924). Momenty wychowawcze. Warszawa-Łódź: Spółka Akcyjna "Nasza Księgarnia".

Kowalik, S. (2001). Pomiędzy dyskryminacją i integracją osób niepełnosprawnych, (w:) B. Kaja (red.), Wspomaganie rozwoju. Psychostymulacja. Psychokorekcja, Bydgoszcz: Wydawnictwo Naukowe AB.

Lindsay, S., Proulx, M., Scott, H., Thomson, N. (2014). Exploring teachers' strategies for including children with autism spectrum disorder in mainstream classrooms, International Journal of Inclusive Education, 18 (2), 101-122, https:/ / doi.org/10.1080/13603116.2012.758320.

Meirieu, P. (2003). Moralne wybory nauczycieli: etyka i pedagogika, tłum. T. Grzegorczyk, Warszawa: Fraszka Edukacyjna.

Mueller, C. (2019). Adolescent understandings of disability labels and social stigma in school. International Journal of Qualitative Studies in Education (QSE), 32 (3), 263-281, https://doi.org/10.1080/09518398.2019.1576940.

Novak, K., Rose, D. (2016). UDL Now! A Teacher's Guide to Applying Universal Design for Learning in Today's Classrooms, CAST Inc. Kindle Edition.

Olechnowicz, H. (1999). U źródeł rozwoju dziecka, Warszawa: WSiP.

Plichta, P. (2010). Uczniowie niepełnosprawni intelektualnie jako ofiary i sprawcy agresji rówieśniczej - kontekst edukacyjny. (w:) J. Pyżalski, E. Roland (red.), Bullying a specjalne potrzeby edukacyjne, Łódź: Wyższa Szkoła Pedagogiczna w Łodzi, za: https://www.academia.edu/20270549/Plichta_P_2010_Uczniowie_niepe\%C5\%82no sprawni_intelektualnie_jako_ofiary_i_sprawcy_agresji_r\%C3\%B3wie\%C5\%9Bniczej_ kontekst_edukacyjny_w_J_P_y\%C5\%BCalski_E_Roland_red_Bullying_a_specjalne_p otrzeby_edukacyjne_Podr\%C4\%99cznik_metodyczny_WSP_w_\%C5\%81odzi_Centru m_Bada\%C5\%84_Behawioralnych_Uniwersytetu_Stavanger_ROBUSD_(access 16.03.2021). 
Plichta, P. (2017). Socjalizacja i wychowanie dzieci i młodzieży z niepetnosprawnościa intelektualna w erze cyfrowej, Torun: Wydawnictwo Adam Marszałek, za:

https://www.researchgate.net/publication/322632496_Plichta_P_2017_Socjalizacja_i _wychowanie_dzieci_i_mlodziezy_z_niepelnosprawnoscia_intelektualna_w_erze_cyf rowej_Torun_Wydawnictwo_Adam_Marszalek_s_308 (access: 16.03.2021).

Plichta, P., Jagoszewska, I., Gładyszewska-Cylulko, J., Szczupał, B., Drzazga, A., Cytowska, B. (2017). Specjalne potrzeby edukacyjne uczniów z niepetnosprawnościami. Charakterystyka, specyfika edukacji i wsparcie, Kraków: Oficyna Wydawnicza Impuls.

Plichta, P. (2019). Przemoc rówieśnicza a specjalne potrzeby edukacyjne. Uwarunkowania zjawiska i propozycje rozwiązań profilaktycznych, (w:) P. Kostyło (red.), Szkoła równych szans. Namyst teoretyczny i rozwiązania praktyczne, 300-316, Bydgoszcz: UKW.

Plichta, P. (2020). Różne konteksty nierówności cyfrowych a wyzwania dla zdalnej edukacji propozycje rozwiązań, (w:) J. Pyżalski (red.), Edukacja w czasach pandemii wirusa COVID-19. Z dystansem o tym, co robimy obecnie jako nauczyciele, 70-80, Warszawa: EduAkcja, za: https://www.researchgate.net/publication/340789562_Pyzalski_J_red_2020_Edukac ja_w_czasach_pandemii_wirusa_COVID-

19_Z_dystansem_o_tym_co_robimy_obecnie_jako_nauczyciele_Warszawa_EduAkcja (access: 16.03.2021).

Poleszak, W., Pyżalski J. (2020). Psychologiczna sytuacja dzieci i młodzieży w dobie epidemii. (w:) J. Pyżalski (red.), Edukacja w czasach pandemii wirusa COVID-19. Z dystansem o tym, co robimy obecnie jako nauczyciele, 7-15, Warszawa: EduAkcja, za: https://www.researchgate.net/publication/340789562_Pyzalski_J_red_2020_Edukac ja_w_czasach_pandemii_wirusa_COVID-

19_Z_dystansem_o_tym_co_robimy_obecnie_jako_nauczyciele_Warszawa_EduAkcja (access: 16.03.2021).

Pyżalski, J., Plichta, P. (2015). Wsparcie ze strony szkoły, do której uczęszcza dziecko (w:) J. Pyżalski, D. Podgórska-Jachnik (red.), Raport końcowy: Badanie potrzeb i satysfakcji z wybranych ustug skierowanych do rodzin z dziećmi z orzeczona niepetnosprawnościa w wieku 8-16 lat, 85-121, Łódź: Regionalne Centrum Polityki Społecznej w Łodzi, http://www.imp.lodz.pl/upload/aktualnosci/2016/raport.pdf (access: 16.03.2021).

Pyżalski, J. (2019). Kształtowanie pozytywnych relacji uczniów w edukacji włączającej, (w:)

G. Szumski, I. Chrzanowska (red.), Edukacja włączajaca w przedszkolu i szkole, 218-227.

Warszawa: Fundacja Rozwoju Systemu Edukacji, za:

https://www.researchgate.net/publication/340789562_Pyzalski_J_red_2020_Edukac ja_w_czasach_pandemii_wirusa_COVID-

19_Z_dystansem_o_tym_co_robimy_obecnie_jako_nauczyciele_Warszawa_EduAkcja (access: 16.03.2021). 
Riley, C., (2006). Disability and Business: Best Practices and Strategies for Inclusion (Disability Library), University Press of New England.

Rozporządzenie Ministra Edukacji Narodowej w sprawie zasad organizacji i udzielania pomocy psychologiczno-pedagogicznej $\mathrm{w}$ publicznych przedszkolach, szkołach i placówkach z dnia 9 sierpnia 2017 r. (z uwzględnieniem późniejszych zmian).

Schwab, S. (2015). Social dimensions of inclusion in education of 4th and 7th grade pupils in inclusive and regular classes: outcomes from Austria, Research in Developmental Disabilities, 4, 72-79, https:/ / doi.org/10.1016/j.ridd.2015.06.005.

Sciutto, M, Richwine, S, Mentrikoski, J, Niedzwiecki, K. (2012). A Qualitative Analysis of the School Experiences of Students With Asperger Syndrome, Focus on Autism and Other Developmental Disabilities, 27 (3), 177-178, https://doi.org/10.1177\%2F1088357612450511.

Shifrer, D. (2013). Stigma of a label: Educational expectations for high school students labeled with learning disabilities, Journal of Health and Social Behavior, 54 (4), 462-480, https:/ / doi.org/10.1177\%2F0022146513503346.

Skrzypiec, G., Askell-Williams, H., Slee, P., Rudzinski, A. (2016). Students with self-identified special educational needs and disabilities (si-SEND): flourishing or languishing!, International Journal of Disability, Development and Education, 63, 7-26, https://doi.org/10.1080/1034912X.2015.1111301.

Szumski, G. (2019). Koncepcja edukacji włączającej, (w:) G. Szumski, I. Chrzanowska (red.), Edukacja właczająca w przedszkolu $i$ szkole, 14-25, Warszawa: Fundacja Rozwoju Systemu Edukacji.

Venetz, M., Zurbriggen, C., Schwab, S. (2019). What Do Teachers Think About Their Students' Inclusion? Consistency of Students' Self-Reports and Teacher Ratings, Frontiers In Psychology, 10, 16-37, https:/ / doi.org/10.3389/fpsyg.2019.01637.

Walentynowicz-Moryl, K. (2016). Wymiar społeczny zdrowia, Relacje. Studia z nauk społecznych, 1, 71-81.

Wehmeyer, M.L., Shogren, K.A., Singh, N.N., Uyanik, H. (2017). Strengths-Based Approaches to Intellectual and Developmental Disabilities, (in:) K. Shogren, M. Wehmeyer, N. Singh (eds.), Handbook of Positive Psychology in Intellectual and Developmental Disabilities. Springer Series on Child and Family Studies. Cham: Springer.

Zhu, M., Urhahne, D. (2014). Assessing teachers' judgements of students' academic motivation and emotions across two rating methods, Educational Research and Evaluation, 20, 411-427, https://doi.org/10.1080/13803611.2014.964261. 